$\underline{\text { Case Reports }}$

\title{
Severe Acute Hepatitis B Treated With Entecavir.
}

Giuseppe Vittorio Luigi De Socio*, Alessio Sgrelli, Andrea Tosti and Franco Baldelli.

Department of Infectious Diseases "Santa Maria della Misericordia” Hospital, University of Perugia, Perugia Italy.

Correspondence to: Giuseppe Vittorio L De Socio, MD. Clinica di Malattie Infettive, Università degli Studi di Perugia. Ospedale "Santa Maria della Misericordia", piazzale Menghini, 1 - 06129 Perugia, Italy. Phone: +39-0755784321, Fax:+39-075-5784346, E-mail: giuseppedesocio@yahoo.it

Competing interests: The authors have declared that no competing interests exist.

Published: March 15, 2011

Received: January 04, 2011

Accepted: Febrary 05, 2011

Mediterr J Hematol Infect Dis 2011, 3: e2011010, DOI 10.4084/MJHID.2011.010

This article is available from: http://www.mjhid.org/article/view/7536

This is an Open Access article distributed under the terms of the Creative Commons Attribution License (http://creativecommons.org/licenses/by/2.0), which permits unrestricted use, distribution, and reproduction in any medium, provided the original work is properly cited.

Hepatitis B virus (HBV) infection constitutes a serious global health problem. Nowadays there are divergent data regarding the use of antiviral drugs to treat acute hepatitis $B$. We present here a case of a 62-year-old man affected by severe acute hepatitis B with progressive worsening of clinical and hepatic function. The patient was treated with entecavir without critical side effects. We observed rapid clinical and laboratory improvements and the disappearance of hepatitis $B$ surface antigen (HBsAg). The treatment with entecavir was protracted until $17^{\text {th }}$ week when the antibody anti-HBs appeared. Entecavir should be carefully considered for the treatment of severe acute hepatitis B cases.

Introduction: Acute hepatitis B viral (HBV) infection can sometimes take a severe course, leading to liver failure due to hepatic necrosis with a death rate of $80 \%{ }^{1-2}$ Emergency liver transplantation is often the only therapeutic option available. ${ }^{3}$ There are many drugs approved for the treatment of chronic hepatitis $\mathrm{B}$, that inhibit the replication of the HBV with a low toxicity and a good resistance profile such lamivudine, adefovir, tenofovir, entecavir and telbivudine. Given their safety, these drugs may represent a reasonable therapeutic option also in severe acute hepatitis B..$^{3-6}$ The new guidelines endorsed by America Association for the study of liver diseases (AASLD) recommend to treat symptomatic acute hepatitis in patients affected with fulminant hepatitis and by severe acute hepatitis B and suggesting the use of lamivudine or telbivudine when the anticipated duration of treatment is short; otherwise, entecavir is preferred. $^{7}$
Patients are considered to have severe acute viral hepatitis B if they fulfill 2 of 3 criteria: (1) hepatic encephalopathy; (2) serum bilirubin level > $10.0 \mathrm{mg} / \mathrm{dL}$; and (3) international normalized ratio $\left(\right.$ INR) $>1.6^{7-9}$

Case Report: A 62-year-old Italian man was admitted to the hospital because of jaundice, fever, fatigue, loss of appetite and dark urine. His history was negative for any major illness, nor alcohol or drugs abuse. He referred unprotect sexual contact two months before. At hospital admission the examination showed a frank jaundice and hepatomegaly. No splenomegaly, nor flapping tremor, nor sleep or digestive disorders were observed. The laboratory exams showed alanine aminotransferase (ALT) $2304 \mathrm{mU} / \mathrm{mL}$, aspartate aminotransferase (AST) $1595 \mathrm{mU} / \mathrm{mL}$, gamma glutamil trans peptidase $(\gamma \mathrm{GT}) 389 \mathrm{mU} / \mathrm{mL}$, direct bilirubin 
level $6.64 \mathrm{mg} / \mathrm{dL}$, total bilirubin level $9.53 \mathrm{mg} / \mathrm{dL}$, prothrombin time activity percentage (PT) $64 \%$, INR 1.30, Glycaemia level $98 \mathrm{mg} / \mathrm{dL}$, ammonia $88 \mathrm{mg} / \mathrm{dL}$, total cholesterol $117 \mathrm{mg} / \mathrm{dL}$, HDL-cholesterol 13 $\mathrm{mg} / \mathrm{dL}$. Hepatitis B markers were hepatitis B surface antigen (HBsAg) positive, quantitative $\mathrm{HBsAg}$ $>250.00 \mathrm{UI} / \mathrm{ml}$, antibodies anti surface antigen (anti$\mathrm{HBs}$ ) were negative, antibodies to e antigen (anti-HBe) and antibodies to core antigen (anti-HBc) IgM both positive, IgM index (sample/cut-off ratio) 25.98, HBV DNA $534258 \mathrm{UI} / \mathrm{mL}$. The other hepatitis virus markers (HAV, HCV, HDV, EBV, CMV) were all negative for acute infection. His serologic test was diagnostic for acute hepatitis B and the diagnosis was strongly supported by the finding of high IgM core index. ${ }^{10}$ To correct the INR we administered $10 \mathrm{mg}$ per day of phytomenadione for three days without improvement. The patient showed a progressive worsening of the clinical conditions with slight mental confusion, sleepwake rhythm alteration, reduction of alertness, anorexia, fever, marked asthenia, jaundice worsening, spleen enlargement (one $\mathrm{cm}$ from the costal arch) and increasing hepatomegaly.

The laboratory examination showed a worsening condition: INR 1.49, ammonia $105 \mathrm{mg} / \mathrm{dL}$, total cholesterol $94 \mathrm{mg} / \mathrm{dL}$, HDL cholesterol $12 \mathrm{mg} / \mathrm{dL}$ AST $2237 \mathrm{mU} / \mathrm{mL}$, ALT $3034 \mathrm{mU} / \mathrm{mL}$, total bilirubin level $19.36 \mathrm{mg} / \mathrm{dL}$. Electroencephalogram (EEG) showed anomalies of the background activities, while the abdominal echography confirmed the presence of hepato-splenomegaly and marked the presence of small ascitic fluid that wasn't detected when the patient was hospitalized.

At this stage, the patient presented criteria of severe acute hepatitis B, thus together with general supportive therapies as glucose solutions iv and lactulose solutions po, we started "off label" treatment with entecavir 1 mg daily. The patient was informed that the drug was not approved for this indication and he gave the consent for the treatment. After three days of antiviral treatment the patient was stably apiretic, while after ten days anorexia, mental confusion, sleep-wake rhythm alteration, asthenia disappeared, jaundice and hepatomegaly were reduced. Ten days after the start of entecavir treatment, the laboratory exams confirmed the improvement of hepatic function: INR 1.21, ammonia $79 \mathrm{mg} / \mathrm{dL}$, total cholesterol level $159 \mathrm{mg} / \mathrm{dL}$, AST $72 \mathrm{mU} / \mathrm{mL}$, ALT $261 \mathrm{mU} / \mathrm{mL}$, total bilirubin level $13.29 \mathrm{mg} / \mathrm{dL}$ (Figure 1). Hepatitis markers revealed: HBsAg and quantitative HBsAg both negative and HBV DNA $65 \mathrm{UI} / \mathrm{mL}$ (Figure 1).

The patient was discharged after 15 days from the beginning of the antiviral treatment. At follow-up after three weeks from starting entecavir, ascitic effusions disappeared, the liver and spleen dimension and coagulation parameters were all normalized. Therapy was continued with entecavir $1 \mathrm{mg}$ day for five weeks, the dosage was decreased to $0.5 \mathrm{mg}$ as the patient experienced a growth of hair loss. HBV DNA wasn't detected after six weeks (figure 1). We continued the treatment with entecavir until the 17th week, when the anti-HBs appeared $(15 \mathrm{UI} / \mathrm{mL})$.

Discussion: We observed rapid improvement of a severe acute hepatitis B treated with entecavir, in accordance with previous reports. ${ }^{3,6,11}$ In medical literature there are divergent data regarding the use of antiviral drugs to treat acute severe hepatitis B. For instance, lamivudine has proved no better than placebo, ${ }^{8}$ while others showed a reduction of mortality rate. ${ }^{4,6}$ Theoretically lamivudine or telbivudine would be a reasonable choice given their safety and rapidity of action. Unfortunately HBV-resistance to lamivudine is increasingly reported. Monotherapy with entecavir, a new generation drug, showed encouraging preliminary results in patients affected by acute severe hepatitis B. ${ }^{3,6,11}$ Furthermore clinical trials of long-term entecavir treatment of chronic hepatitis B have shown a very low rate of resistance to this drug compared with other antiviral. So in severe acute hepatitis B, this drug seems to be a good reasonable choice when resistance profile is high or the patient could be considered at risk of infection by resistant virus. ${ }^{7}$ Tenofovir and adefovir may not be optimal because of their potential for nephrotoxicity. ${ }^{7}$ We didn't know the patient's viral HBV resistance profile, so for safety and according to Jochum et $\mathrm{al}^{11}$ we used entecavir at the dose of $1 \mathrm{mg}$ for day considering the approved dose for lamivudine resistant patients. ${ }^{7}$

The main concerns about the use of anti-HBV drugs during the acute phase are principally linked to two factors: first, the antiviral therapy is generally not necessary because more than $95 \%$ of acute infections solve spontaneously. ${ }^{7}$ Second, early antiviral therapy theoretically may inhibit the production of neutralizing antibody in the early phase of the disease and delays the appearance of anti-HBs. In a recent study lamivudine used in acute hepatitis B has been reported to determine a reduced anti-HBs seroconversion as compared to patients not receiving the antiviral, ${ }^{4}$ even if other studies did not observe significant differences. ${ }^{8}$ Usually anti-HBs appear after one - two months from HBsAg disappearance, although in some patients not being treated with antiviral drugs, antibodies could not appear in weeks or even months. ${ }^{12}$ In the reported case, antibodies anti-HBs appeared after about four months 


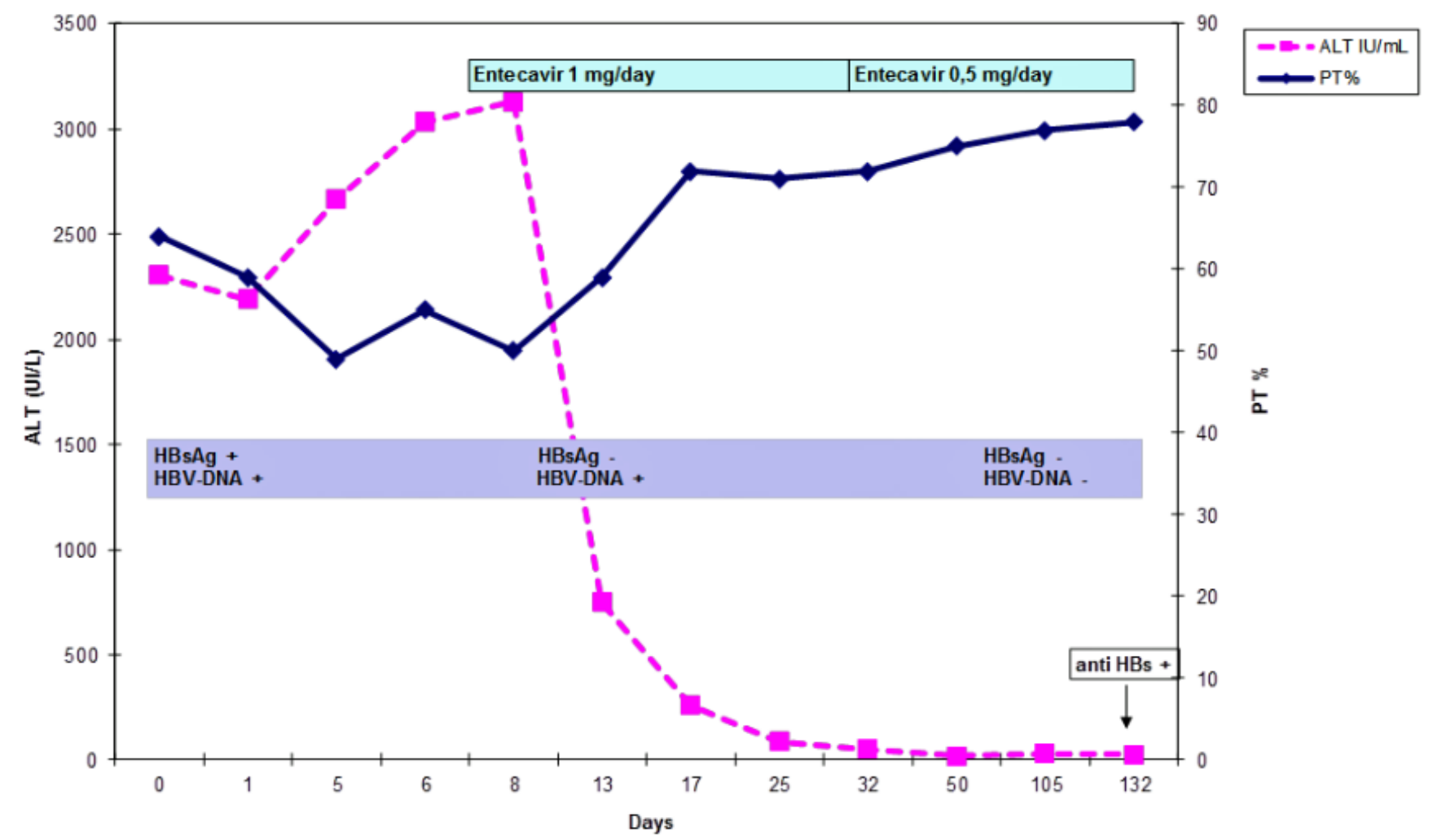

Figure 1. Biochemical and viral parameters at admission and subsequent controls. Alanine aminotransferase (ALT) UI/mL, prothrombin time activity percentage (PT), hepatitis B antigen (HBsAg) UI/mL, antibody antiHBs (anti HBs), Hepatitis B DNA (HBV-DNA) UI/mL.

from the disappearance of the HBsAg. The duration of antiviral treatment is not established; we stopped entecavir at seroconversion to anti-HBs. However, this issue is still controversial: EASL guidelines recommend therapy to be continued for at least 3 months after anti-HBs appearance, ${ }^{13}$ while AASLD ones until HBsAg clearance is confirmed. ${ }^{7}$ Further studies are necessary to support the appropriateness and the duration of entecavir treatment in cases of acute severe hepatitis B. Meanwhile the possible use of this drug should be considered for selected patients with acute hepatitis B.

\section{References:}

1. Wright TL, Lau JY. Clinical aspects of hepatitis B virus infection. Lancet. 1993; 342:1340-1344. doi:10.1016/01406736(93)92250-W

2. Antoniu E, Luca V. Features of clinical evolution of severe acute viral hepatitis. Series of 72 cases. Rev Med Chir Soc Med Nat Iasi. 2010; 114: 95-100. PMid:20509283

3. De Socio GV, Mercuri A, Di Candilo F, Baldelli F. Entecavir to treat severe acute hepatitis B. Scand J Infect Dis. 2009; 41: 703-704. doi:10.1080/00365540903062705 PMid:19544224

4. Yu JW, Sun LJ, Zhao YH, Kang P, Li SC. The study of efficacy of lamivudine in patients with severe acute hepatitis B. Dig Dis Sci. 2010; 55: 775-783. doi:10.1007/s10620-009-1060-5 PMid:19957031

5. Schiff E, Simsek H, Lee WM, Chao YC, Sette H Jr, Janssen HL, Han SH, Goodman Z, Yang J, Brett-Smith H,
Acknowledgments: We would like to express our sincere gratitude to the patient who granted permission to publish these data.

Conflict Of Interest Statement: All authors hereby state that no financial and personal relationships with other people, or organizations, exist which could influence (bias) this work inappropriately.

All authors contributed to the critical revision of the article and approval of the final manuscript.
Tamez R. Efficacy and safety of entecavir in patients with chronic hepatitis B and advanced hepatic fibrosis or cirrhosis. Am J Gastroenterology 2008; 103: 2776-2783. doi:10.1111/j.1572-0241.2008.02086.x PMid:18721244

6. Girke J, Wedemeyer H, Wiegand J, Manns MP, Tillmann HL. Acute hepatitis B: is antiviral therapy indicated? Two case reports. Dtsch Med Wochenschr. 2008; 133:11781782. doi:10.1055/s-2008-1077235 PMid: 18491273

7. Lok A S F, McMahon BJ. Chronic Hepatitis B: Update 2009. AASLD practice guideline update. Hepatology 2009; 50: 661-662. doi:10.1002/hep.23190 PMid:19714720

8. Kumar M, Satapathy S, Monga R, Das K, Hissar S, Pande C, Sharma BC, Sarin SK. A randomized controlled trial of lamivudine to treat acute hepatitis B. Hepatology. 2007; 45:97-101. doi:10.1002/hep.21486 PMid:17187417 
9. Schmilovitz-Weiss H, Ben-Ari Z, Sikuler E, Zuckerman E, Sbeit W, Ackerman Z, Safadi R, Lurie Y, Rosner G, TurKaspa R, Reshef R. Lamivudine treatment for acute severe hepatitis B: a pilot study. Liver International 2004; 24 : $547-551$.

PMid: 15566503

10. Rodella A, Galli C, Terlenghi L, Perandin F, Bonfanti C, Manca N. Quantitative analysis of HBsAg, IgM anti-HBc and anti-HBc avidity in acute and chronic hepatitis B. J Clin Virol. 2006; 37: 206-12. doi:10.1016/j.jcv.2006.06.011 PMid:16893678

11. Jochum C, Gieseler RK, Gawlista I, Fiedler A, Manka P, Saner FH, Roggendorf M, Gerken G, Canbay A. Hepatitis
B-associated acute liver failure: immediate treatment with entecavir inhibits hepatitis B virus replication and potentially its sequelae. Digestion. 2009;80:235-40. doi:10.1159/000236009 PMid:19828954

12. Curry MP, Chopra S. Acute viral hepatitis. In: Mandell GL, Bennett JE, Dolin R. Churchill Livingstone. Principles and practice of Infectious Diseases seventh edition. 2010; 1577 1592.

13. EASL Clinical Practice Guidelines: management of chronic hepatitis B. European Association For The Study Of The Liver. J Hepatol. 2009;50:227-42. doi:10.1016/j.jhep.2008.10.001 PMid:19054588 